\title{
IMPACT ANALYSIS TESTS USING FEMAP ADVANCED EXPLICIT DYNAMIC SOLVER
}

\author{
Dumitru-Silviu Perijoc \\ "Dunarea de Jos" University of Galati, \\ Faculty of Naval Architecture, Galati, \\ 47 Domneasca Street, 800008, Romania, \\ E-mail: silviu.perijoc@ugal.ro
}

\author{
Leonard Domnișoru \\ "Dunarea de Jos" University of Galati, \\ Faculty of Naval Architecture, Galati, \\ 47 Domneasca Street, 800008, Romania, \\ E-mail: leonard.domnisoru@ugal.ro
}

\author{
Cristi-Marian Angheluță \\ "Dunarea de Jos" University of Galati, \\ Faculty of Naval Architecture, Galati, \\ 47 Domneasca Street, 800008, Romania, \\ E-mail: marian.angheluta@ugal.ro
}

\begin{abstract}
As part of the continuum growth of the shipping industry, new challenges arise for the engineers. The development of floating structures capable of withstanding accidental loads, such as grounding and ship collisions, become nowadays an integral part of the design process. The current paper presents a methodology for impact analysis using FEMAP software capabilities in two distinct stages. The first stage consists of the impact analysis using a rigid indenter displaced at different speeds. The second stage of the study evaluates the impact analysis considering both the indenter and the structure deformable. Mesh influence tests, as well as the influence of the type of elements used in the analysis, have been taken into consideration in the present study.
\end{abstract}

Keywords: impact analysis, Femap, material failure, equivalent plastic strain.

\section{INTRODUCTION}

The advancement in computational power enables a consequent approach of developing large finite element models for marine structures, thus complex phenomena such as ship collision and grounding analysis become manageable [3]. Following the trend of development in computational power, benchmark program suites for structural analysis, such as Siemens Femap [1], introduce in accordance with the demands of the industry, new approaches in numerical analysis and material failure description.

The present study presents a brief insight in the use of Femap [1] for impact structural analysis, considering two types of structures, a simple and stiffened plate. Both structures were subjected to impact, taking into account

(C) Galati University Press, 2020 the indenter as rigid and deformable, traveling at different speeds. (see Table 1)

\section{MATERIAL MODEL AND FAILURE CRITERIA}

Nonlinear plastic material formulation was used, described by the bilinear stress-strain curve (Fig.1), according to AND [2] material properties formulation for marine graded steel, having the yield stress $235 \mathrm{MPa}$.

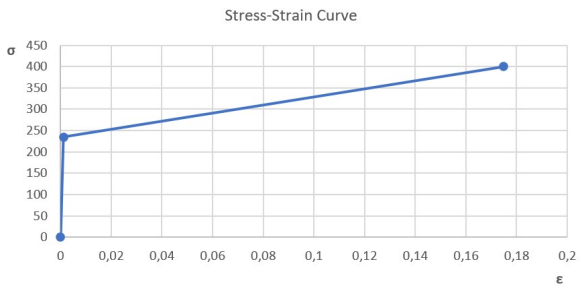

Figure 1. Stress-Strain curve (AND) [2] 
Material nonlinearity and rupture failure is controlled by the Advanced Explicit Dynamic Solver (SOL 701) used for solving highly dynamic problems of short duration. The initial von Mises yield criterion was use, having the nonlinear properties isotropic, the hardening rule and the stress-strain curve as the function dependence in Figure 1.

Table 1. Analysed cases

\begin{tabular}{|c|c|c|c|c|c|}
\hline Case & $\begin{array}{l}\text { Plate } \\
\text { type }\end{array}$ & $\begin{array}{c}\text { Indenter } \\
\text { type }\end{array}$ & $\begin{array}{c}\mathrm{v} \\
{[\mathrm{m} / \mathrm{s}]}\end{array}$ & $\begin{array}{c}\text { Elem. Size } \\
{[\mathrm{mm}]}\end{array}$ & $\mu_{\mathrm{c}}$ \\
\hline 1 & SP & Rigid & 2 & 50 & 0 \\
\hline 2 & SP & Rigid & 2 & 50 & 0,6 \\
\hline 3 & SP & Rigid & 2 & 25 & 0 \\
\hline 4 & SP & Rigid & 2 & 25 & 0,6 \\
\hline 5 & SP & Deformable & 2 & 50 & 0 \\
\hline 6 & SP & Deformable & 2 & 50 & 0,6 \\
\hline 7 & SP & Deformable & 2 & 25 & 0 \\
\hline 8 & SP & Deformable & 2 & 25 & 0,6 \\
\hline 9 & SP & Rigid & 5 & 50 & 0 \\
\hline 10 & SP & Rigid & 5 & 50 & 0,6 \\
\hline 11 & SP & Rigid & 5 & 25 & 0 \\
\hline 12 & SP & Rigid & 5 & 25 & 0,6 \\
\hline 13 & SP & Deformable & 5 & 50 & 0 \\
\hline 14 & SP & Deformable & 5 & 50 & 0,6 \\
\hline 15 & SP & Deformable & 5 & 25 & 0 \\
\hline 16 & SP & Deformable & 5 & 25 & 0,6 \\
\hline 17 & $\begin{array}{l}\text { ST_PL } \\
\end{array}$ & Rigid & 2 & 50 & 0 \\
\hline 18 & ST_PL & Rigid & 2 & 50 & 0,6 \\
\hline 19 & ST_PL & Rigid & 2 & 25 & 0 \\
\hline 20 & ST_PL & Rigid & 2 & 25 & 0,6 \\
\hline 21 & ST PL & Deformable & 2 & 50 & 0 \\
\hline 22 & ST_PL & Deformable & 2 & 50 & 0,6 \\
\hline 23 & ST_PL & Deformable & 2 & 25 & 0 \\
\hline 24 & ST_PL & Deformable & 2 & 25 & 0,6 \\
\hline 25 & ST_PL & Rigid & 5 & 50 & 0 \\
\hline 26 & ST PL & Rigid & 5 & 50 & 0,6 \\
\hline 27 & ST_PL & Rigid & 5 & 25 & 0 \\
\hline 28 & ST_PL & Rigid & 5 & 25 & 0,6 \\
\hline 29 & ST PL & Deformable & 5 & 50 & 0 \\
\hline 30 & ST_PL & Deformable & 5 & 50 & 0,6 \\
\hline 31 & ST PL & Deformable & 5 & 25 & 0 \\
\hline 32 & ST PL & Deformable & 5 & 25 & 0,6 \\
\hline
\end{tabular}

\section{GEOMETRY AND FEM MODEL}

The geometry model consists of a 4000x4000x10 mm plate. The indenter geometry was represented by a semi-sphere object with a diameter of $1000 \mathrm{~mm}$. For the case including the deformable indenter, same dimension of the semi-sphere was considered and two stiffeners plates were added. A thickness of $10 \mathrm{~mm}$ was considered for the deformable indenter shell and stiffeners. (Figure 2,3). For the second impacted structure, two $350 \times 10 \mathrm{~mm}$ stiffeners were added. (Figure 4,5)

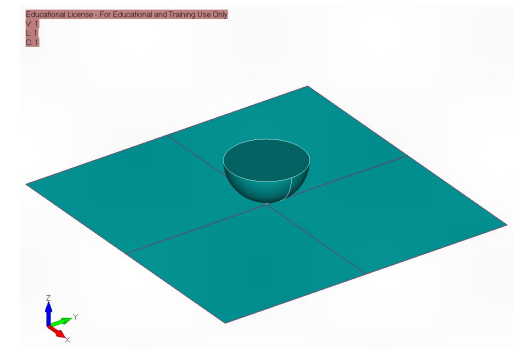

Figure 2. Simple plate - Rigid indenter

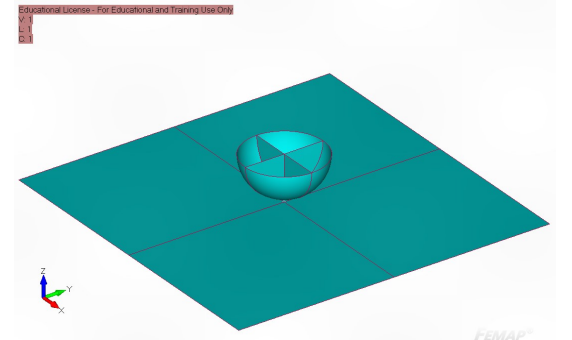

Figure 3. Simple plate - Deformable indenter

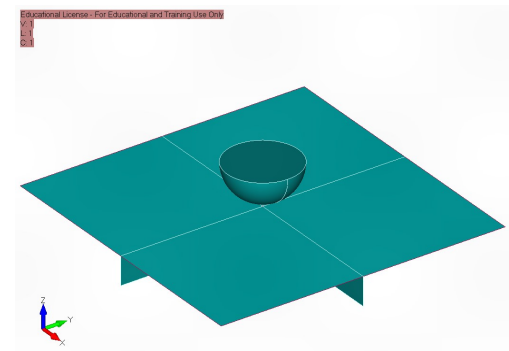

Figure 4. Stiffened plate - Rigid indenter

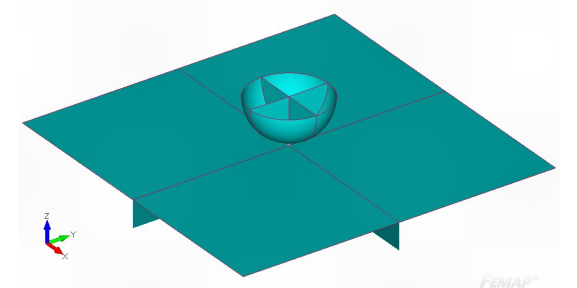

Figure 5. Stiffened plate - Deformable indenter

For the finite element models, the mesh size dimensions of $50 \mathrm{~mm}$ and $25 \mathrm{~mm}$ are considered, as well as a value of the friction coefficient of $\mu=0.6$. A total of 32 analysis cases are included in the study.

(C) Galati University Press, 2020 


\section{Results and discussions}

For the impacted simple plate with the rigid and deformable indenter and the velocity of $2 \mathrm{~m} / \mathrm{s}$ (case 1-8), the next results are obtained: -Table 2 presents the total contact force variation for rigid and deformable indenters, 50-25 $\mathrm{mm}$ mesh size and a friction coefficient value of $0-0.6$;

-Table 3 presents the von Mises stress of the impacted plate with the rigid and deformable indenter;

-Figures 6-8 present the resulting von Mises stress resulted following the rigid and deformable indenter impact.

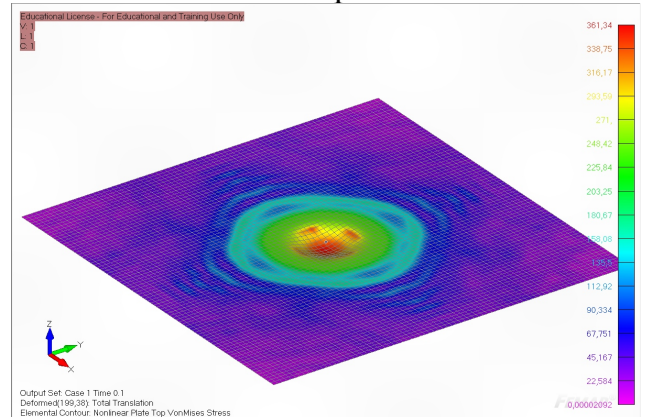

Figure 6. Case 2 - Plate - von Mises stress

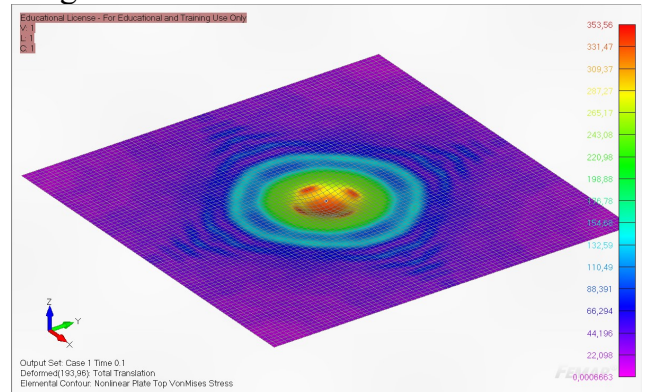

Figure 7. Case 5 - Plate - von Mises stress

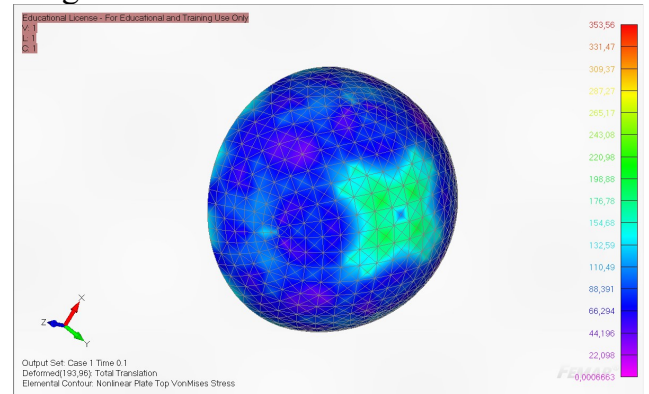

Figure 8. Case 5 - Indenter - von Mises stress

(C) Galati University Press, 2020
Table 2. Total contact force $-2 \mathrm{~m} / \mathrm{s}$

\begin{tabular}{|c|c|c|c|c|}
\hline \multirow{2}{*}{ Case } & \multirow{2}{*}{$\begin{array}{c}\text { Indenter } \\
\text { type }\end{array}$} & $\begin{array}{c}\text { Elem. } \\
\text { Size }\end{array}$ & \multirow{2}{*}{$\mu$} & $\begin{array}{c}\text { Total } \\
\text { Contact } \\
\text { Force }\end{array}$ \\
\cline { 3 - 4 } \cline { 5 - 5 } & {$[\mathrm{mm}]$} & & {$[\mathrm{MN}]$} \\
\hline 1 & Rigid & 50 & 0 & 2,030 \\
\hline 2 & Rigid & 50 & 0,6 & 2,030 \\
\hline 3 & Rigid & 25 & 0 & 1,312 \\
\hline 4 & Rigid & 25 & 0,6 & 1,312 \\
\hline 5 & Deform. & 50 & 0 & 1,251 \\
\hline 6 & Deform. & 50 & 0,6 & 1,251 \\
\hline 7 & Deform. & 25 & 0 & 1,035 \\
\hline 8 & Deform. & 25 & 0,6 & 1,035 \\
\hline
\end{tabular}

Table 3. von Mises stress $-2 \mathrm{~m} / \mathrm{s}$

\begin{tabular}{|c|c|c|c|c|}
\hline \multirow{2}{*}{ Case } & \multirow{2}{*}{$\begin{array}{c}\text { Indenter } \\
\text { type }\end{array}$} & $\begin{array}{c}\text { Elem. } \\
\text { Size }\end{array}$ & \multirow{2}{*}{$\mu$} & $\sigma_{\mathrm{VM}}$ \\
\cline { 3 - 4 } \cline { 5 - 5 } & {$[\mathrm{mm}]$} & & {$[\mathrm{Mpa}]$} \\
\hline 1 & Rigid & 50 & 0 & 367,07 \\
\hline 2 & Rigid & 50 & 0,6 & 361,34 \\
\hline 3 & Rigid & 25 & 0 & 371,92 \\
\hline 4 & Rigid & 25 & 0,6 & 354,06 \\
\hline 5 & Deform. & 50 & 0 & 353,56 \\
\hline 6 & Deform. & 50 & 0,6 & 343,57 \\
\hline 7 & Deform. & 25 & 0 & 354,79 \\
\hline 8 & Deform. & 25 & 0,6 & 351,32 \\
\hline
\end{tabular}

The obtained results for cases 9-16, corresponding to the $5 \mathrm{~m} / \mathrm{s}$ velocity of the indenter, are described in the following:

-Table 4 presents the total contact force variation for rigid and deformable indenter;

-Table 5 presents the damage volume ratio dependent of the indenter type, mesh dimension and frictional coefficient;

Table 4. Total contact force $-5 \mathrm{~m} / \mathrm{s}$

\begin{tabular}{|c|c|c|c|c|}
\hline \multirow{2}{*}{ Case } & \multirow{2}{*}{$\begin{array}{c}\text { Indenter } \\
\text { type }\end{array}$} & $\begin{array}{c}\text { Elem. } \\
\text { Size }\end{array}$ & \multirow{2}{*}{$\mu$} & $\begin{array}{c}\text { Total } \\
\text { Contact } \\
\text { Force }\end{array}$ \\
\cline { 3 - 5 } \cline { 5 - 5 } & & {$[\mathrm{mm}]$} & & {$[\mathrm{MN}]$} \\
\hline 9 & Rigid & 50 & 0 & 5,020 \\
\hline 10 & Rigid & 50 & 0,6 & 5,020 \\
\hline 11 & Rigid & 25 & 0 & 3,211 \\
\hline 12 & Rigid & 25 & 0,6 & 3,211 \\
\hline 13 & Deform. & 50 & 0 & 3,075 \\
\hline 14 & Deform. & 50 & 0,6 & 3,074 \\
\hline 15 & Deform. & 25 & 0 & 2,914 \\
\hline 16 & Deform. & 25 & 0,6 & 2,913 \\
\hline
\end{tabular}


-Figures 9,10 and 11 present the total deformation and von Mises stress distribution of the plate and indenter for the deformable case. The rigid indenter cases point out a clean structural failure of the plate with very small out of plane rotations of the elements.

Table 5. Damage volume ratio - $5 \mathrm{~m} / \mathrm{s}$

\begin{tabular}{|c|c|c|c|c|}
\hline \multirow{2}{*}{ Case } & \multirow{2}{*}{$\begin{array}{c}\text { Indenter } \\
\text { type }\end{array}$} & $\begin{array}{c}\text { Elem. } \\
\text { Size }\end{array}$ & \multirow{2}{*}{$\mu$} & $\begin{array}{c}\text { Damage } \\
\text { volume }\end{array}$ \\
\cline { 3 - 4 } \cline { 5 - 5 } & & {$[\mathrm{mm}]$} & & ratio \\
\hline 9 & Rigid & 50 & 0 & $4,13 \%$ \\
\hline 10 & Rigid & 50 & 0,6 & $4,13 \%$ \\
\hline 11 & Rigid & 25 & 0 & $4,86 \%$ \\
\hline 12 & Rigid & 25 & 0,6 & $4,57 \%$ \\
\hline 13 & Deform. & 50 & 0 & $2,23 \%$ \\
\hline 14 & Deform. & 50 & 0,6 & $2,22 \%$ \\
\hline 15 & Deform. & 25 & 0 & $3,34 \%$ \\
\hline 16 & Deform. & 25 & 0,6 & $2,71 \%$ \\
\hline
\end{tabular}

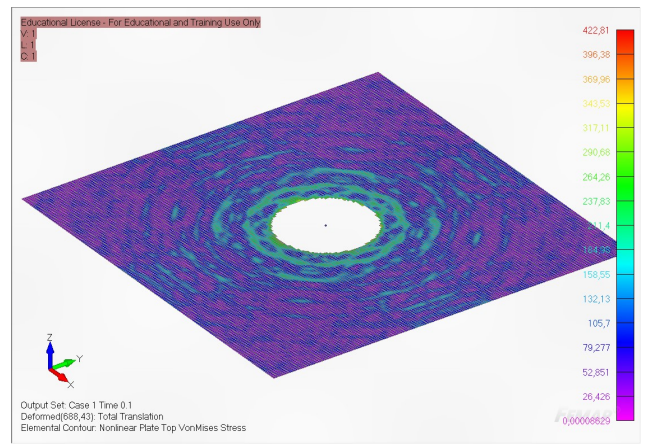

Figure 9. Case 12 - Rigid indenter impact

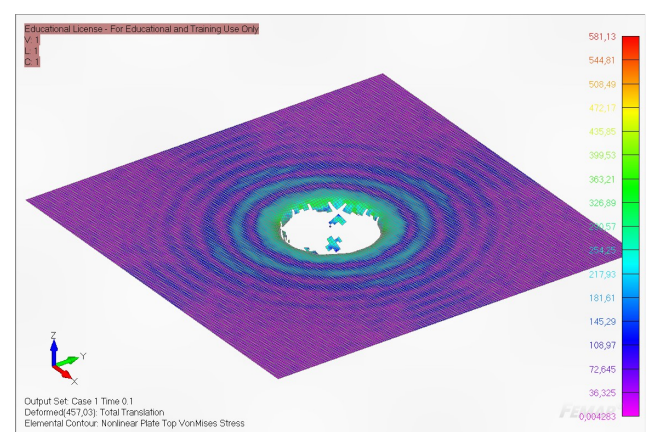

Figure 10. Case 16 - Deformable indenter impact

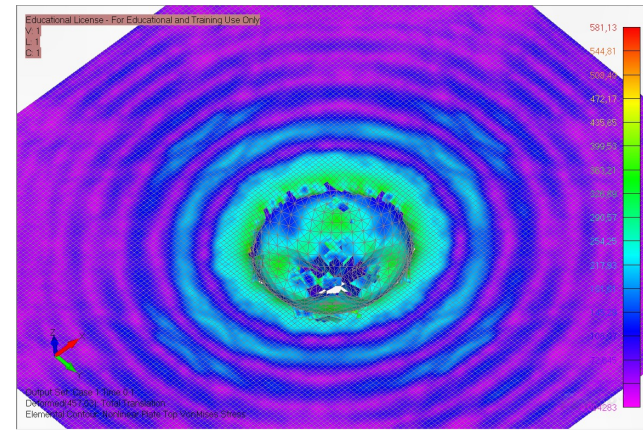

Figure 11. Case 16 - Deformable indenter

For analysed cases 17-24, and the indenter speed of $2 \mathrm{~m} / \mathrm{s}$, the following results are obtained:

-Table 6 presents the total contact force resulting after impact.

-Table 7 includes the damage volume ratio resulted after structural failure.

-Figure 12,13,14 presents the von Mises stress distribution and the total deformation occurred on the stiffened panel, as well as on the deformable indenter.

The rigid impact cases register higher values for von Mises stress distribution around the indenter contact area. The combinations of deformations affecting the indenters shape due to impact lead to an overall increase in the stress distribution on the stiffened plate. Structural failure (rupture) was identified for cases 17-20, considering the rigid indenter. Mesh sensitivity can be observed for cases 21 24 , corresponding to the deformable indenter, where for the mesh size of $50 \mathrm{~mm}$ no element failure was present.

\begin{tabular}{|c|c|c|c|c|}
\multicolumn{3}{|c|}{ Table 6. Total contact force - $\mathbf{2 ~ m / s}$} \\
\hline \multirow{2}{*}{ Case } & \multirow{2}{*}{$\begin{array}{c}\text { Indenter } \\
\text { type }\end{array}$} & $\begin{array}{c}\text { Elem. } \\
\text { Size }\end{array}$ & $\mu$ & $\begin{array}{c}\text { Total } \\
\text { Contact } \\
\text { Force }\end{array}$ \\
\cline { 3 - 4 } \cline { 5 - 5 } & & {$[\mathrm{mm}]$} & & {$[\mathrm{MN}]$} \\
\hline 17 & Rigid & 50 & 0 & 2,827 \\
\hline 18 & Rigid & 50 & 0,6 & 2,827 \\
\hline 19 & Rigid & 25 & 0 & 1,756 \\
\hline 20 & Rigid & 25 & 0,6 & 1,755 \\
\hline 21 & Deform. & 50 & 0 & 1,536 \\
\hline 22 & Deform. & 50 & 0,6 & 1,536 \\
\hline 23 & Deform. & 25 & 0 & 1,356 \\
\hline 24 & Deform. & 25 & 0,6 & 1,357 \\
\hline
\end{tabular}


Table 7. Damage volume ratio $-2 \mathrm{~m} / \mathrm{s}$

\begin{tabular}{|c|c|c|c|c|}
\hline \multirow{2}{*}{ Case } & \multirow{2}{*}{$\begin{array}{c}\text { Indenter } \\
\text { type }\end{array}$} & $\begin{array}{c}\text { Elem. } \\
\text { Size }\end{array}$ & \multirow{2}{*}{$\mu$} & $\begin{array}{c}\text { Damage } \\
\text { volume }\end{array}$ \\
\cline { 3 - 5 } \cline { 5 - 5 } & & {$[\mathrm{mm}]$} & & ratio \\
\hline 17 & Rigid & 50 & 0 & $0,13 \%$ \\
\hline 18 & Rigid & 50 & 0,6 & $0,04 \%$ \\
\hline 19 & Rigid & 25 & 0 & $0,43 \%$ \\
\hline 20 & Rigid & 25 & 0,6 & $0,45 \%$ \\
\hline 21 & Deform. & 50 & 0 & - \\
\hline 22 & Deform. & 50 & 0,6 & - \\
\hline 23 & Deform. & 25 & 0 & $0,28 \%$ \\
\hline 24 & Deform. & 25 & 0,6 & $0,28 \%$ \\
\hline
\end{tabular}

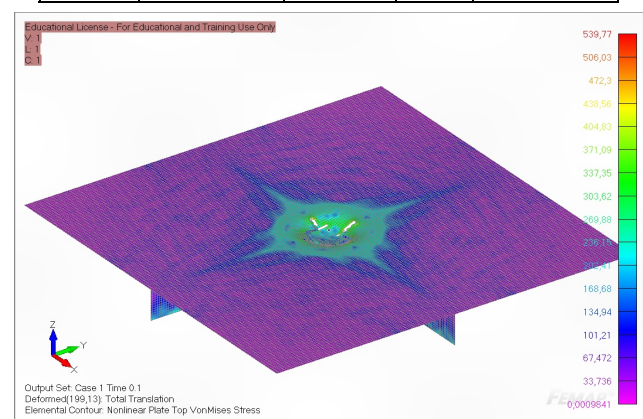

Figure 12. Case 20 - Rigid indenter $-2 \mathrm{~m} / \mathrm{s}$

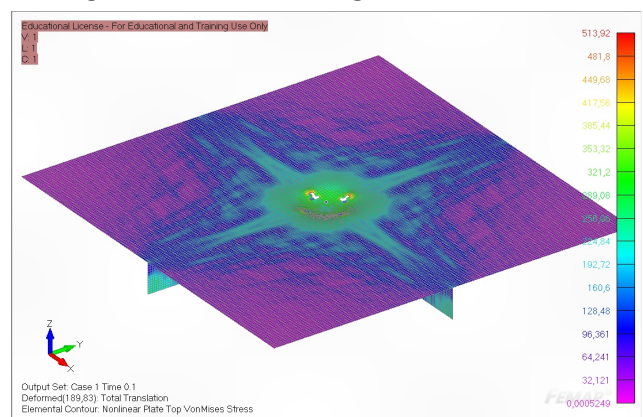

Figure 13. Case 24 - Deformable indenter $-2 \mathrm{~m} / \mathrm{s}$

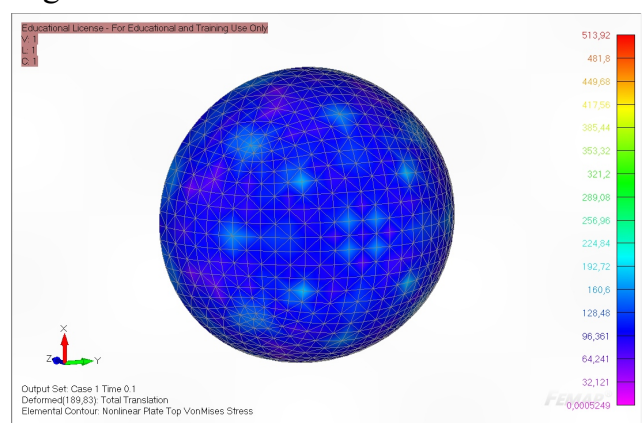

Figure 14. Case 24 - Deformable indenter - $2 \mathrm{~m} / \mathrm{s}$
Results for cases 25-32 and indenters velocity of $5 \mathrm{~m} / \mathrm{s}$, are presented in the following section:

-Table 8 presents the total contact force.

-Table 9 presents the damage volume ratio.

-Figure 15 presents the von Mises stress distribution and the total deformation of the eroded stiffened panel due to rigid impact.

-Figure 16 presents the von Mises stress distribution following the impact of the stiffened plate with the deformable indenter.

-Figure 17 presents the von Mises stress distribution and deformation for the structure of the indenter.

For the impact cases considering the deformable indenter, out of plane element deformations occurred for both the stiffened plate structure, as well as for the structure of the indenter.

Table 8. Total contact force $-5 \mathrm{~m} / \mathrm{s}$

\begin{tabular}{|c|c|c|c|c|}
\hline \multirow{2}{*}{ Case } & \multirow{2}{*}{$\begin{array}{c}\text { Indenter } \\
\text { type }\end{array}$} & $\begin{array}{c}\text { Elem. } \\
\text { Size }\end{array}$ & \multirow{2}{*}{$\mu$} & $\begin{array}{c}\text { Total } \\
\text { Contact } \\
\text { Force }\end{array}$ \\
\cline { 3 - 4 } \cline { 5 - 5 } & {$[\mathrm{mm}]$} & & {$[\mathrm{MN}]$} \\
\hline 25 & Rigid & 50 & 0 & 6,839 \\
\hline 26 & Rigid & 50 & 0,6 & 6,839 \\
\hline 27 & Rigid & 25 & 0 & 4,353 \\
\hline 28 & Rigid & 25 & 0,6 & 4,353 \\
\hline 29 & Deform. & 50 & 0 & 6,939 \\
\hline 30 & Deform. & 50 & 0,6 & 6,939 \\
\hline 31 & Deform. & 25 & 0 & 4,212 \\
\hline 32 & Deform. & 25 & 0,6 & 4,212 \\
\hline
\end{tabular}

Table 9. Damage volume ratio - $5 \mathrm{~m} / \mathrm{s}$

\begin{tabular}{|c|c|c|c|c|}
\hline \multirow{2}{*}{ Case } & \multirow{2}{*}{$\begin{array}{c}\text { Indenter } \\
\text { type }\end{array}$} & $\begin{array}{c}\text { Elem. } \\
\text { Size }\end{array}$ & \multirow{n}{*}{$\mu$} & \begin{tabular}{c} 
Damage \\
volume \\
\cline { 3 - 5 }
\end{tabular} \\
\cline { 3 - 5 } & {$[\mathrm{mm}]$} & & ratio \\
\hline 25 & Rigid & 50 & 0 & $4,69 \%$ \\
\hline 26 & Rigid & 50 & 0,6 & $4,36 \%$ \\
\hline 27 & Rigid & 25 & 0 & $4,40 \%$ \\
\hline 28 & Rigid & 25 & 0,6 & $4,28 \%$ \\
\hline 29 & Deform. & 50 & 0 & $2,98 \%$ \\
\hline 30 & Deform. & 50 & 0,6 & $2,78 \%$ \\
\hline 31 & Deform. & 25 & 0 & $3,52 \%$ \\
\hline 32 & Deform. & 25 & 0,6 & $2,77 \%$ \\
\hline
\end{tabular}

(c) Galati University Press, 2020 


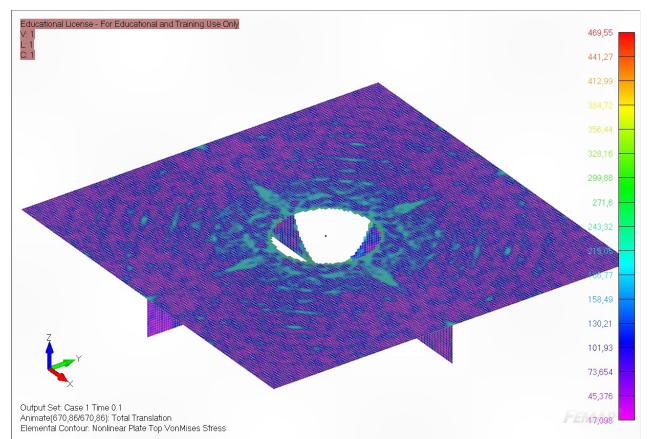

Figure 15. Case 28 - Rigid indenter impact$5 \mathrm{~m} / \mathrm{s}$

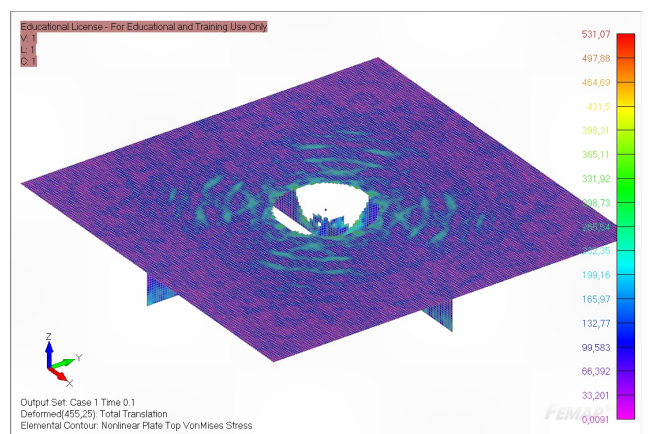

Figure 16. Case 32 - Deformable indenter impact $-5 \mathrm{~m} / \mathrm{s}$

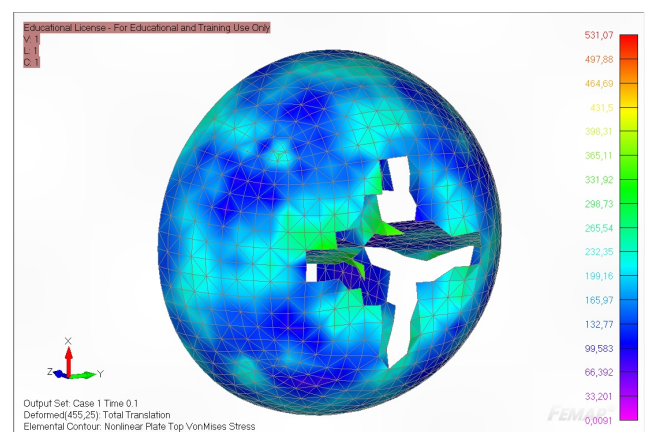

Figure 17. Case 32 - Deformable indenter impact $-5 \mathrm{~m} / \mathrm{s}$

\section{CONCLUSIONS}

The current study presents a brief overview for impact analysis using Femap Advanced Explicit Dynamic solver. The Equivalent von Mises Plastic Strain failure criteria $\left(\varepsilon_{\mathrm{r}}=0.1748, \sigma_{\mathrm{r}}=400 \mathrm{MPa}\right)$ was used for evaluating structural rupture (AND [2]), taking into consideration the cases of rigid and deformable indenter.

The conclusions following the 32 analysed cases are presented below:

1. Significant differences were obtained for impact analysis considering the indenter rigid or deformable. The damage ratio volume resulted in a smaller value for the cases with deformable indenter.

2. Mesh sensitivity was found to be of great importance in performing the analyses, with significant influence on total contact force and also on the damage volume ratio.

3. The frictional coefficient of 0.6 used in the performed analyses introduced small variation of the damage volume ratio (0.1$0.75 \%)$.

4. The total contact force variation was found to be dependent on the mesh size. As the mesh density increased, the local stiffness of the model decreased, resulting in a lower total contact force.

5. Further comparison studies between numerical and experimental data have to be performed in order to validate the numerical solutions.

\section{Acknowledgements}

This study is developed in the framework of the Naval Architecture Research Centre, "Dunarea de Jos" University of Galati.

\section{REFERENCES}

[1]. FNN, "Femap/NX Nastran users' manual", Siemens PLM Software Inc., 2020.

[2]. AND, European agreement concerning the international carriage of dangerous goods by inland waterways (Vol. I), 2019. https://doi.org/10.18356/91419305-en

[3]. ISSC, "Proceeding of the 20th ISSC Congress", IOS Press, Amsterdam, 2018.

Paper received on October $31^{\text {th }}, 2020$ 